\title{
Effect of Aqueous Extracts of Peppermint (Mentha $\times$ piperita L.) on the Germination and the Growth of Selected Vegetable and Cereal Seeds
}

\author{
Katarzyna MOŻDŻÉ́ ${ }^{1 *}$, Beata BARABASZ-KRASNY², \\ Alina STACHURSKA-SWAKON ${ }^{3}$, Peiman ZANDI ${ }^{4}$, Joanna PUŁA ${ }^{5}$ \\ ${ }^{1}$ Pedagogical University of Kraków, Institute of Biology, Department of Plant Physiology, Podchorażych 2 St., 30-084 Kraków, \\ Poland; katarzyna.mozdzen@up.krakow.pl( (*orrespondingauthor) \\ ${ }^{2}$ Pedagogical University of Kraków, Institute of Biology, Department of Botany, Podchorązych 2 St., 30-084 Kraków, \\ Poland; beata.barabasz-krasny@up.krakow.pl \\ 3agiellonian University, Institute of Botany, Gronostajowa 3 St., 30-387Kraków, Poland; alina.stachurska-swakon@uj.edu.pl \\ ${ }^{4}$ Institute of Environment and Sustainable, Development in Agriculture, Chinese Academy of Agricultural Sciences Beijing 100081, P.R. \\ China; z_rice_b@yahoo.com \\ ${ }^{5}$ University of Agriculture, Faculty of Agriculture and Economics, Al. Mickiewicza 21 Ave, 31-120 Kraków, Poland; rrpula@cyf-kr.edu.pl
}

\begin{abstract}
Peppermint (Mentha $\times$ piperita L.) is grown in the gardens for its attractive look and multilateral use in the kitchen and medicine. The grown plant spreads very easily producing stolons and could effectively compete with other plant species. For the purpose of this study, the effect of aqueous extracts from dry peppermint leaves was examined on the germination, growth, fresh and dry weight, and electrolytes leakage of 10 species commonly grown in different regions of the world: Beta vulgaris L., Cucumis sativus L., Lactuca sativa L., Lupinus luteus L., Phaseolus vulgaris L., Raphanus sativus L. var. radicula Pers., Sinapis alba L., Lycopersicon esculentum Mill., Triticum aestivum L., and Zea mays L. Several concentrations of the aqueous extracts from peppermint leaves were prepared: $1,3,5,10$, and $15 \%$. The seeds germination decreased with increasing concentration of aqueous extracts from peppermint leaves. The seed germination was completely inhibited on Petri dishes with 10 and $15 \%$ extracts. The tomato seeds were the most sensitive, they germinated on the distilled water and $1 \%$ extract only. The most resistant were the bean seeds that had the highest germination capacity. In general, the growth of seedlings of analyzed species was inhibited by the aqueous extracts from peppermint leaves. However, it was noticed the stimulating effect on the seedling growth of bean and maize on the $1 \%$ extract. The aqueous extracts from peppermint leaves caused the electrolyte leakage in all examined species and it raised with increasing extract concentration at the concentration higher than $3 \%$.
\end{abstract}

Keywords: allelopathy; aqueous extracts; cereals; germination capacity; peppermint; vegetables

\section{Introduction}

One of the obstacles to the development of organic farming is competition between plants being the consequence of interaction known as allelopathy (Kieć and Wieczorek, 2009; Sekutowski, 2010). The significant part of studies on this phenomenon relates to the weed - crop relationship, which illustrates synergistic or antagonistic interactions (de Albuquerque et al., 2011). These interactions are associated with the production of specific chemical compounds in plants called allelopathins (Jezierska-Domaradzka, 2007; Jezierska-Domaradzka and Kuźniewski, 2007). These compounds belong to the group of plant secondary metabolites. They are released from plants into the environment in many ways, e.g., as volatile substances from aboveground parts, leaching from the leaves, excretion from the roots or during the decomposition. In general, leaves are believed to produce and contain the highest level of allelopathins. The lowest level of the secondary metabolites was found in seeds and fruits (Rice, 1984). Allelochemical substances act through direct interference with the physiological functions of 'receiver', such as seed germination, root growth, shoot growth, stem growth, symbiotic effectiveness or act indirectly through additive or synergistic impact along with pathological infections, insect injury and/or environmental stress (Dahiya et al., 2017). 
Numerous experiments demonstrated the inhibitory effect of extracts made from native weed species on germination and early growth of cereals (Ciesielska and Borkowska, 2010; Kraska and Kwiecinska-Poppe, 2007; Marczewska-Kolasa et al., 2017), germination of legumes, e.g. beans (Phaseolus vulgaris L.), and other vegetables, as pumpkin (Cucurbita pepo L.) or tomato (Lycopersicon esculentum Mill.) (Kadioglu et al., 2005). Allelopathic effects of extracts were also documented on cultivated plants, e.g., Sorghum vulgaris L., buckwheat (Fagopyrum esculentum Moench), common sunflower (Helianthus annus L.) (Macias et al., 2002; Tsuzuki and Dong, 2003), lemon balm (Melissa officinalis L.), white mulberry (Morus alba L.) (Mozdzen and Repka, 2014), lavender (Lavandula angustifolia Mill.) (Teaca et al., 2008), or peppermint (Mentha $\times$ piperita L.) (Skrzypek et al., 2015a, b, 2016). However, the allelopathic potential of many of these crop plants is still not sufficiently known, such an example is peppermint.

Peppermint (Mentha $\times$ piperita L., Lamiaceae) is a spontaneous hybrid of $M$. aquatica $\mathrm{L}$. and $M$. spicata $\mathrm{L}$. em. L. It probably emerged in England and was cultivated from the 18th century (Szweykowska and Szweykowski, 2003). Currently, mint is planted all over the world and used as a flavoring in the kitchen, food industry, as well as a source of essential oils widely used in pharmacy (especially aromatherapy) and cosmetology (Rita and Animesh, 2011; Bufalo et al., 2015). The most frequently, leaves (Folium Menthae piperitae) and mint herb (Herba Menthae piperitae) are used due to the highest content of biologically active substances in these organs. Its main chemical compounds are essential oils (mainly peppermint oil containing, among others, menthol), flavonoids, glycosides, acids (e.g. ascorbic acid) and mineral compounds (Czikow and Laptiew, 1983; Mystkowska et al., 2016).

The aim of the present study was to examine the allelopathic influence of Mentha $\times$ piperita extracts on seed germination (i), growth (ii), biomass (iii), and electrolyte leakage (iv) of 10 vegetable and cereals taxa commonly grown in different regions of the world: common beetroot Beta vulgaris L., cucumber Cucumis sativus L., lettuce Lactuca sativa L., yellow lupine Lupinus luteus L., common bean Phaseolus vulgaris L., radish Raphanus sativus L. var. radicula Pers., light mustard Sinapis alba L., common tomato Lycopersicon esculentum Mill., common wheat Triticum aestivum $\mathrm{L}$., and common maize Zea mays $\mathrm{L}$.

\section{Materials and Methods}

\section{Plant material}

Seeds of the studied vegetables (Beta vulgaris, Cucumis sativus, Lactuca sativa, Lupinus luteus, Phaseolus vulgaris, Raphanus sativus var. radicula, Sinapis alba, Lycopersicon esculentum), and cereal species (Triticum aestivum, Zea mays) were obtained from the gardening store Polan sp. z.o.o (Poland), and dry peppermint leaves (Folium Menthae piperitae) from Flos company (Morsko, Poland).

\section{Prepared extract}

Aqueous extracts of peppermint leaves were made at concentrations of $1,3,5,10$, and $15 \%$, weighing the appropriate amount of dry leaves per $100 \mathrm{ml}$ of distilled water. After $24 \mathrm{~h}$ extraction, the extracts were strained using a vacuum pump on a Büchner funnel with Whatman filter paper. The extracts prepared in this way were stored at a temperature of $8^{\circ} \mathrm{C}$ (in the refrigerator) for the duration of the entire experiment.

\section{Seed germination}

Seeds of vegetables and cereals, washed in running and distilled water, were placed on sterile Petri dishes lined with a triple layer of filter paper $\left(105^{\circ} \mathrm{C} / 2 \mathrm{~h}\right)$. It was used 100 morphologically identical seeds of every species per one Petri dish per every extract and control (saturated with distilled water). The plant material was placed in the dark at a constant temperature $\left(25^{\circ} \mathrm{C}\right)$ and humidity condition $(90 \%)$. The number of germinated seeds was counted every 24 h over 7 days. As germinated seeds were considered ones with sprouts of length equal to the $2 \mathrm{~mm}$. Total germination was checked according to the formula GT = $(\mathrm{Nt} \times 100) / \mathrm{N}$, were GT - total germination, $\mathrm{Nt}-$ proportion of germinated seeds at each treatment for the last time, $\mathrm{N}$ - number of seeds used in the bioassay.

\section{leakage}

Length of seedlings, fresh and dry weight, electrolyte

After 7 days, using the caliper (Topex 31C615, Poland), the length of the seedlings was measured and next, the fresh weight (Medicat $1600 \mathrm{C}$, Poland) and dry weight (dryer Termaks 8430, Poland) were determined. The degree of the destabilization of cell membranes was determined by measuring the electrolytes leakage using the method described in Skrzypek et al. (2015a).

\section{Statistical analysis}

The experiment was repeated five times. The differences between the test and control samples were determined by Duncan's parametric test, with $\mathrm{p} \leq 0.05$. The calculations were performed using Statistica for Windows 13.0 software.

\section{Results}

\section{Seed germination}

The germination capacity of the tested seeds decreased with the increase of the concentration of aqueous extracts of Mentha $\times$ piperita leaves. In most species, total inhibition of seed germination was observed on Petri dishes saturated with $15 \%$ extract. Similar germination model was observed for Beta vulgaris, Raphanus sativus var. radicula, Sinapis alba: the number of germinating seeds decreased rapidly already at $1 \%$ of the extract. The most sensitive were Lycopersicon esculentum seeds, which germinated only on the control sample and on Petri dishes saturated with $1 \%$ extracts of mint leaves. Total inhibition of seed germination was found for Lactuca sativa on plates with extracts at 10\% and $15 \%$. Phaseolus vulgaris seeds were the most resistant and they showed the highest germination capacity (with extracts from 1 to $10 \%$ more than $90 \%$ of seeds germinated, the germination was totally inhibited at $15 \%$ concentration only). Zea mays and Cucumis sativus were also resistant to extracts. They responded to the extracts by reducing germination, but even at the highest $15 \%$ concentration of mint leaves, more than $30 \%$ of their seeds germinated (Fig. $1)$. 
414

\section{Length of seedlings}

$P$. vulgaris and $Z$. mays were the only species that showed the stimulating effect of the mint extract on the seedlings growth: it was observed with $1 \%$ aqueous extracts of mint leaves. L. esculentum seedlings were the most sensitive: already at $3 \%$ of the extract, the elongation growth was completely inhibited. In the case of Beta vulgaris, Raphanus sativus var. radicula, and Sinapis alba extracts of mint leaves delayed the elongation irrespective of extract concentration. The smallest inhibiting effect was documented for $P$. vulgaris seedlings; only the $15 \%$ extract inhibited their growth (Table 1).

\section{Fresh and dry weight}

Analyzing the values of fresh and dry weight of seedlings, it was found that mint extracts at concentrations of $1 \%, 3 \%$, and $5 \%$ only slightly inhibited the mass growth. The most inhibiting effect was connected with the highest concentrated extracts -10 and $15 \%$, which clearly limited the growth of seedlings mass, relative to the control (Table 2).

\section{Electrolyte leakage}

With increasing concentrations of mint extracts, an increase in electrolyte flow through the cell membranes of seedlings was observed, as compared to the control sample. Extracts with concentrations of 1 and $3 \%$ did not cause
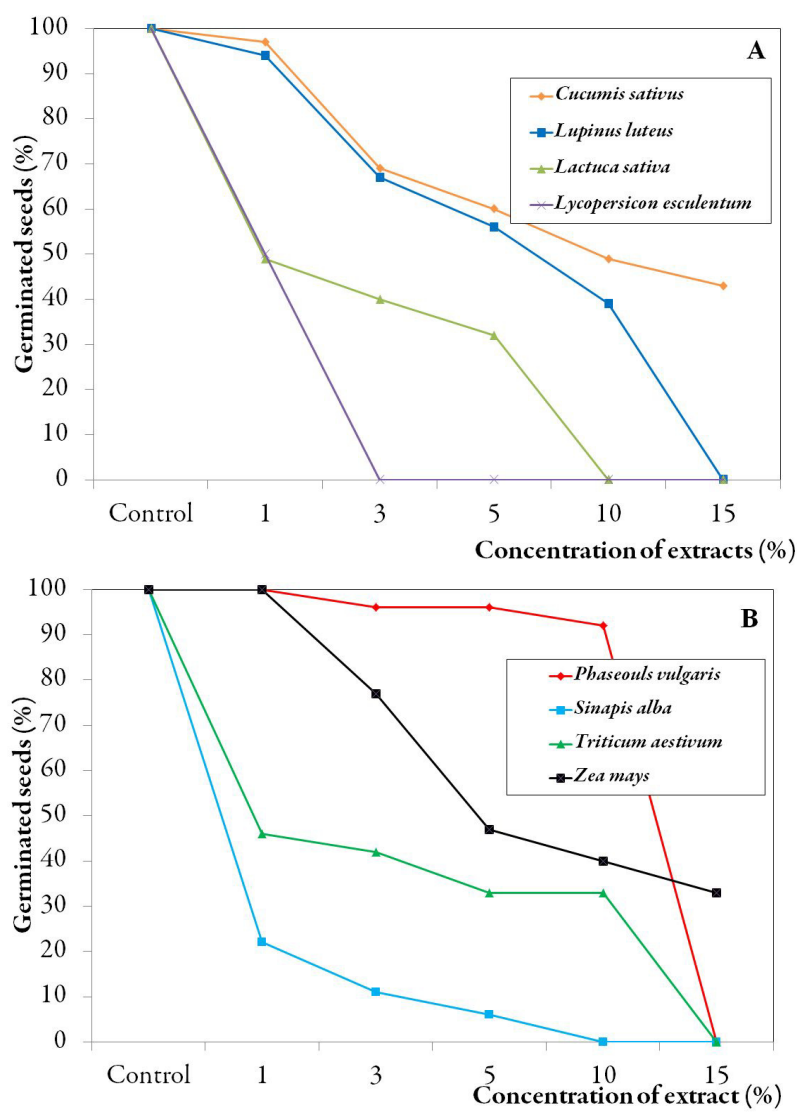

Fig. 1. The germination capacity of seeds of selected cultivated plants species on substrates with aqueous extracts of peppermint leaves (Mentha $\times$ piperita L.), at concentrations of $1,3,5,10$ and $15 \%$ statistically significant changes in the destabilization of cell membranes. L. esculentum seedlings were the only exception, in whom the extract with a concentration of $3 \%$ caused a 4-fold increase in electrolyte leakage from the cells, as compared to the control. Extracts of 5\% and higher affected seedlings of all studied species, an increase of electrolyte leakage was demonstrated. The largest over $90 \%$ destabilization of the ionic economy in the cells of all tested seedlings was found at the $15 \%$ concentration of the extract (Table 3).

\section{Discussion}

In the soil environment, the allelopathic effect depends on the concentration of active compounds in the soil rhizosphere and their interaction with soil contents, organic matter and factors that alter the physicochemical and biotic properties of soils (Blum and Shafer, 1988). Increased evapotranspiration and lower soil moisture may result in reduced phytotoxicity of allelopathic compounds in the soil substratum. The level of toxins in the soil depends also on the soil type, its aeration, temperature and microbial activity.

For example, loamy soils are poorly permeable and toxins do not diffuse easily in them. In contrast, sandy soils are well-permeable and have a tendency for maximum leaching and easy diffusing, including allelochemicals. Plants sensitive to toxins may be more vulnerable when planted in heavy soils (Dahiya et al., 2017). Taking into consideration the relationship between phytotoxins and soil properties, it could be important to control the presence of plant species that coexist and compete with crop plants.

The germination of seeds is influenced by many external factors, including water availability, soil $\mathrm{pH}$, temperature or light. The internal factors also play a key role, such as the state of the embryo, the level of hormones and enzymes activated in the semen (Koger et al., 2004). Appropriate germination of seeds results in the appearance of hypocotyl and root. The root is the first part of the seedling, which under certain conditions is responsible for chemical changes that have a subsequent effect on the growth of the hypocotyl, as a result of the absorption of water and minerals. If the seedling root is in the suitable conditions for growth, it gets the substances needed for the development. Otherwise, the surrounding environment causes disturbances in the absorption capacity of water and

Table 1. The length of seedlings of the studied cultivated species, which germinated on substrates with aqueous extracts of peppermint leaves (Mentha $\times$ piperita L.), at concentrations of 1, 3, 5, 10 and 15\%

\begin{tabular}{clcccccc}
\hline \multirow{2}{*}{ No. } & \multirow{2}{*}{ Seedlings } & \multicolumn{6}{c}{ Concentration extract (\%) } \\
\cline { 3 - 8 } & & 0 & 1 & 3 & 5 & 10 & 15 \\
\hline 1. & Beta vulgaris & 3.4 & 2.1 & $1.5^{*}$ & $0.9^{*}$ & $0.2^{*}$ & $0.0^{*}$ \\
\hline 2. & Cucumis sativus & 3.6 & 3.4 & 2.4 & 2.0 & $1.4^{*}$ & $0.0^{*}$ \\
\hline 3. & Lactuca sativa & 1.4 & $0.6^{*}$ & $0.6^{*}$ & $0.5^{*}$ & $0.0^{*}$ & $0.0^{*}$ \\
\hline 4. & Lupinus luteus & 3.6 & 3.4 & 2.4 & $2.0^{*}$ & $1.4^{*}$ & $0.0^{*}$ \\
\hline 5. & Phaseouls vulgaris & 2.5 & 2.8 & 2.4 & 2.4 & 2.3 & $0.0^{*}$ \\
\hline 6. & Raphanus sativus v. radicula & 3.5 & $1.7^{*}$ & $1.0^{*}$ & $0.7^{*}$ & $0.5^{*}$ & $0.0^{*}$ \\
\hline 7. & Sinapis alba & 3.6 & $0.8^{*}$ & $0.4^{*}$ & $0.2^{*}$ & $0.0^{*}$ & $0.0^{*}$ \\
\hline 8. & Lycopersicon esculentum & 0.6 & 0.3 & $0.0^{*}$ & $0.0^{*}$ & $0.0^{*}$ & $0.0^{*}$ \\
\hline 9. & Triticum aestivum & 2.4 & 1.1 & 1.0 & $0.8^{*}$ & $0.8^{*}$ & $0.0^{*}$ \\
\hline 10. & Zea mays & 4.3 & 4.5 & 3.3 & $2.0^{*}$ & $1.7^{*}$ & $1.4^{*}$ \\
\hline Note: values $\left( \pm\right.$ SD) marked with $\left({ }^{*}\right)$ & differ & significantly & according to Duncan's
\end{tabular}
test at $\mathrm{p}<0.05 .0$ - control 
Table 2. The fresh (A) and dry (B) weight (g) of the studied cultivated species seedlings, which germinated on substrates with aqueous extracts of peppermint leaves (Mentha $\times$ piperita L.), at concentrations of 1,3, 5, 10 and $15 \%$

\begin{tabular}{|c|c|c|c|c|c|c|c|c|c|c|c|c|c|}
\hline \multirow{3}{*}{ No. } & \multirow{3}{*}{ Seedlings } & \multirow{2}{*}{\multicolumn{2}{|c|}{ Control }} & \multicolumn{10}{|c|}{ Concentration of extract (\%) } \\
\hline & & & & \multicolumn{2}{|c|}{1} & \multicolumn{2}{|c|}{3} & \multicolumn{2}{|c|}{5} & \multicolumn{2}{|c|}{10} & \multicolumn{2}{|c|}{15} \\
\hline & & $\mathrm{A}$ & $\mathrm{B}$ & $\mathrm{A}$ & $\mathrm{B}$ & $\mathrm{A}$ & $\mathrm{B}$ & $\mathrm{A}$ & B & $\mathrm{A}$ & $\mathrm{B}$ & $\mathrm{A}$ & $\mathrm{B}$ \\
\hline 1. & Beta vulgaris & 0.54 & 0.25 & 0.41 & 0.16 & 0.30 & 0.11 & 0.29 & 0.10 & $0.15^{*}$ & $0.06^{*}$ & $0.12^{*}$ & $0.04^{*}$ \\
\hline 2. & Cucumis sativus & 1.48 & 0.65 & 1.42 & 0.63 & 1.44 & 0.66 & 1.21 & 0.67 & 1.12 & 0.69 & $1.11^{*}$ & 0.69 \\
\hline 3. & Lactuca sativa & 0.12 & 0.02 & 0.09 & 0.03 & 0.07 & 0.03 & 0.08 & 0.02 & $0.05^{*}$ & 0.02 & $0.06^{*}$ & 0.02 \\
\hline 4. & Lupinus luteus & 10.58 & 2.63 & 8.70 & 2.82 & 8.71 & $3.03^{*}$ & 8.51 & 2.81 & 8.31 & 3.00 & $6.70^{*}$ & 3.00 \\
\hline 5. & Phaseolus vulgaris & 14.08 & 4.18 & 10.29 & 3.29 & 11.53 & 3.71 & 11.45 & 3.85 & $9.30^{*}$ & 3.32 & $8.46^{*}$ & 4.26 \\
\hline 6. & Raphanus sativus var. radicula & 0.81 & 0.28 & 0.81 & 0.24 & 0.65 & 0.25 & 0.58 & 0.27 & $0.53^{*}$ & 0.26 & $0.49^{*}$ & 0.26 \\
\hline 7. & Sinapis alba & 0.63 & 0.15 & 0.39 & 0.14 & 0.42 & 0.18 & 0.41 & 0.18 & $0.35^{*}$ & 0.17 & $0.38^{*}$ & 0.19 \\
\hline 8. & Lycopersicon esculentum & 0.19 & 0.06 & 0.22 & 0.07 & 0.17 & 0.06 & 0.18 & 0.07 & 0.20 & 0.07 & 0.19 & 0.07 \\
\hline 9. & Triticum aestivum & 2.75 & 0.96 & 1.64 & 0.91 & 1.59 & 0.92 & 1.60 & 0.96 & 1.56 & 0.96 & 1.64 & 1.03 \\
\hline 10 . & Zeamays & 9.27 & 3.32 & 8.50 & 3.26 & 7.61 & 3.33 & 8.67 & 3.28 & 7.35 & 3.29 & $5.89^{*}$ & 3.50 \\
\hline
\end{tabular}

Table 3. The percentage of electrolyte leakage from the cell membranes of the studied cultivated species seedlings, which germinated on substrates with aqueous extracts of peppermint leaves (Mentha $\times$ piperita L.), at concentrations of 1, 3, 5, 10 and 15\%

\begin{tabular}{|c|c|c|c|c|c|c|c|}
\hline \multirow{2}{*}{ No. } & \multirow{2}{*}{ Seedlings } & \multirow{2}{*}{ Control } & \multicolumn{5}{|c|}{ Concentration of extract (\%) } \\
\hline & & & 1 & 3 & 5 & 10 & 15 \\
\hline 1. & Beta vulgaris & 15.21 & 29.10 & 41.45 & $56.99^{*}$ & $78.93^{*}$ & $93.25^{*}$ \\
\hline 2. & Cucumis sativus & 29.39 & 35.40 & 51.89 & $60.29^{*}$ & $71.56^{*}$ & $7929^{*}$ \\
\hline 3. & Lactuca sativa & 19.12 & 39.18 & 42.79 & $44.89^{*}$ & $70.47^{*}$ & $93.99^{*}$ \\
\hline 4. & Lupinus luteus & 30.11 & 32.00 & 40.56 & $50.28^{*}$ & $75.36^{*}$ & $98.39^{*}$ \\
\hline 5. & Phaseolus vulgaris & 30.13 & 40.01 & 48.25 & $59.89^{*}$ & $67.12^{*}$ & $75.89^{*}$ \\
\hline 6. & Raphanus sativus var. radicula & 36.15 & 47.19 & 59.21 & $67.89^{*}$ & $82.26^{*}$ & $94.69^{*}$ \\
\hline 7. & Sinapis alba & 24.25 & 39.23 & 56.06 & $70.59^{*}$ & $88.89^{*}$ & $97.29^{*}$ \\
\hline 8. & Lycopersicon esculentum & 12.19 & 29.39 & 55.89 & $76.36^{*}$ & $80.43^{*}$ & $94.89^{*}$ \\
\hline 9. & Triticum aestivum & 22.89 & 36.00 & 39.02 & $49.29^{*}$ & $56.49^{*}$ & $79.26^{*}$ \\
\hline 10 . & Zeamays & 36.23 & 35.09 & 49.25 & $64.89^{*}$ & $79.56^{*}$ & $85.27^{*}$ \\
\hline
\end{tabular}

minerals, leading to the abnormal growth of the entire seedling (Pula et al., 2016). During this experiment, it was found that aqueous extracts of Mentha $\times$ piperita leaves, regardless of concentration, clearly limited seed germination. In relation to the control, Phaseolus vulgaris seeds showed the highest germination capacity, they were the most resistant to the allelopathins of mint. On the other hand, the most sensitive were seeds of Lycopersicon esculentum, which germinated only on the substrate with $1 \%$ mint extracts and in the control (Fig. 1). Chemical interactions between weeds and crops revealed that substances released from weed remnants affect the germination of neighboring crops (Ridenour and Callaway, 2001). At the same time, the germination efficiency of seeds depends on their size and weight. Large-scale seeds contain more nutrients than small seeds. Therefore, large seeds are capable of faster germination and growth (Nik et al., 2011; Sadeghi et al., 2011; Amin and Brinis, 2013). In the case of seedling elongation, $1 \%$ extracts from $M$. × piperita stimulated the growth of seedlings of $P$. vulgaris and $Z$. mays, relative to the control. A similar tendency of growth was observed by Skrzypek et al. (2015b) in the study of the influence of aqueous extracts of mint leaves on the germination of common sunflower seeds. In this study, in the remaining vegetables and cereals, each of the mint extracts inhibited seedling elongation (Table 1).
Plant phytotoxicity may result from the synergistic reaction of the chemicals produced by them (Saharkhiz et al., 2010). Often, it is the result of the simultaneous action of several compounds and usually affects those compounds whose chemical properties are divergent (Kaur et al., 2010). In the experiment conducted here, the values of fresh and dry weight of seedlings significantly decreased with increasing concentrations of mint extracts, in comparison with the control. The smallest biomass increase was found in seedlings grown on Petri dishes saturated with extracts with the highest concentrations of allelopathins (Table 2). The chemical composition of secondary metabolites, such as allelopathins, depends largely on the plant taxon, its age, origin and environmental factors (Lawrence, 2007; Newerli-Guz, 2016). Biologically active substances produced by plants demonstrate various properties. Some of them are selective for other species, others are not. Some have the ability to inhibit completely and others to slow growth slightly (Dudai et al., 1999; Campiglia et al., 2007; Ayoub et al., 2018). An important role is also played by the plant growth hormones indoleacetic acid (IAA) and gibberellins (GA) that regulate cell extension in plants. IAA is present in both active and inactive forms and is inactivated by IAA-oxidase. IAA-oxidase is inhibited by various allelochemicals (Rice, 1984), other inhibitors block GA and induce extension growth. 
416

It has been demonstrated that the cell membranes of the examined species were destabilized with increasing concentration of mint extracts, relative to the control condition (Table 3). Such seedling reactions can be explained by the presence of biologically active compounds in "donor" plants - peppermint, which act on the components of the recipient cell membranes - analyzed cultivated species (Harper and Balke, 1981). These substances cause, among others, enzyme dysfunction and disturbances of mineral and water absorption, which result in changes in the growth and development of plants (Siyar et al., 2017). The ability to bind many natural plant products with membranes results not only in conformational changes in ion channels and proteins but also increases or decreases ion flux. It was documented that monoterpenoids have a toxic effect on seed germination (Rice, 1984) and interact at the cell level with cytosolic $\mathrm{Ca}^{2+}$, probably through an intracellular $\mathrm{Ca}^{2+}$ store release and $\mathrm{Ca}^{2+}$ channel blocking (Takeuchi et al., 1994; Sanders and Bethke, 2000). According to Griffin et al. (2000), the relative hydrophobicity of most monoterpenoids can accumulate in biological membranes. Additionally, some allelopathins can indirectly contribute to cell death by producing reactive oxygen that causes lipid peroxidation and disintegrates membranes (Golisz et al., 2008; Mutlu et al., 2011).

In agro-ecosystems, weeds compete with arable crops for environmental resources, reducing yields and reducing the quality of crops. As a result, they contribute to financial losses (Lipinska, 2006). The dynamically developing agriculture is still looking for new ways to increase crop production efficiency. However, due to the increase of the environmental pollution, organic farming is becoming more and more popular. Knowledge of the mutual interactions between plant species is one of the important factors that could be conducive to the development of organic farming. It allows to avoid or to reduce the use of different types of pesticides and to obtain better, more fertile, healthy, and tasty crops. Well-chosen plant species will not only protect each other against pests but also better flowering and better use of nutrients contained in the soil. The potential for using allelopathins as natural herbicides or components allowing to reduce the use of artificial chemicals increases year by year (Bhadoria, 2011; Khalaj et al., 2013).

Although many issues related to allelopathy have not yet been resolved, the use of allelopathic compounds for weed suppression remains an "open path" to reduce the use of herbicides. Regardless of whether by the development of natural herbicides from isolated allelopathins or through the use of plants with allelopathic potential, allelopathy will most likely be a way of ensuring sustainable agricultural systems in the future.

\section{Conclusions}

Reduced germination [i], inhibition of seedling elongation [ii], reducing in weight [iii], and increase in electrolyte leakage [iv] in response to aqueous peppermint extracts confirm that the leaves of this species contain biologically active allelopathic compounds. Most likely, the high phytotoxic activity of mint extracts results from the presence of a high concentration of chemical substances well soluble in water, which, under suitable soil conditions, are readily available to plants growing in the closest vicinity.

\section{References}

Amin C, Brinis L (2013). Effect of seed size on germination and establishment of vigorous seedlings in durum wheat (Triticum durum Desf.). Advances in Environmental Biology 7(1):77-81.

Ayoub A, Fatima K, M'hamedE, Mohammed T,El Hassan A, Sanaa Ch,... Tarik A (2018). Chemical study by GC-MS of the essential oils of certain mints grown in the region of Settat (Morocco): Mentha piperita, Mentha pulegium and Mentha spicata. Drug Designing and Intellectual Properties International Journal 1(4):1-4.

Bhadoria PBS (2011). Allelopathy: A natural way towards weed management. American Journal of Experimental Agriculture 1(1):7-20.

Blum U, Shafer SR (1988). Microbial populations and phenolic acids in soil. Soil Biology and Biochemistry 20:793-800.

Bufalo J, Zheljazkov VD, Cantrel, CL, Astatkie T, Ciampa L, Jeliazkova E (2015). Diurnal effects on spearmint oil yields and composition. Scientia Horticulturae 182:73-76.

Campigia E, Mancinelli R, Cavalieri A, Caporali F (2007). Use of essential oils of cinnamon (Cinnamomum zeylanicum L.), lavender (Lavandula spp.) and peppermint (Mentha xpiperita L.) for weed control. Italian Journal of Agronomy 2:171-175.

Ciesielska A, Borkowska M (2010). The effect of aqueous extracts of ground seeds of Agrostemma githago on the germination of winter wheat and barley.Journal of Research and Applications in Agricultural Engineering 55(3):40-43 [in Polish].

Czikow P, Laptiew J (1983). Medicinal plants and rich in vitamins. Panstwowe Wydawnictwo Rolnicze i Leśne, Warszawa p. 227-228 [in Polish].

Dahiya S, Kumar S, Khedwal RS, Jakhar SR (2017). Allelopathy for sustainable weed management. Journal of Pharmacognosy and Phytochemistry 6(SP1):832-837.

de Albuquerque MB, dos Santos RC, Lima LM, de Albuquerque Melo Filho P, Mansur Custódio Nogueira RJ, Gomes da Camara CA, de Rezende Ramos A (2011). Allelopathy, an alternative tool to improve cropping systems. A review. Agronomy for Sustainable Development 31:379-395.

Dudai N, Poljakoff-Mayber A, Mayber AM, Putievsky E, Lerner HR (1999). Essential oils as allelochemicals and their potential use as bioherbicides. Journal of Chemical Ecology 25:1079-1089.

Golisz A, Sugano M, Fujii Y (2008). Microarray expression profiling of Arabidopsis thaliana $\mathrm{L}$. in response to allelochemicals identified in buckwheat.Journal of Experimental Botany 59:3099-3109.

Griffin S, Markham JL, Dennis G, Grant Wyllie S (2000). Using atomic force microscopy to view the effects of terpenoids on the stability and packing of phosphatidylcholine supported lipid bilayers. Proceedings $31^{\star}$ International Symposium on Essential Oils, Hamburg, 10-13 September 2000.

Harper JR, Balke NE (1981). Characterization of the inhibition of K+ absorption in oat roots by salicylic acid. Plant Physiology 68:1349.

Jezierska-Domaradzka A (2007). Allelopathic potential of plants as an opportunity to reduce weed infestation of agricultural crops. Studia i RaportyIUNG 8:23-28 [in Polish].

Jezierska-Domaradzka A, Kuźniewski E (2007). Allelopathic effect of water extracts of Capsella bursa-pastoris (L.) Medik and Stellaria media (L.) Vill 
on germination and juvenile stages of Ocimum basilicum L. and Origanum majorana L. Annales UMCS, Sectio E 62(2):10-16 [in Polish].

Kadioglu I, Yanar Y, Asav U (2005). Allelopathic effects of weeds extracts against seed germination of some plants. Journal of Environmental Biology 26(2):169-173.

Kaur S, Singh HP, Mittal S, Batish DR, Kohli RK(2010). Phytotoxic effects of volatile oil from Artemisia scoparia against weeds and its possible use as a bioherbicide. Industrial Crops and Products 32:5461.

Khalaj MA, Amiri M, Azimi MH (2013). Allelopathy: physiological and sustainable agriculture important aspects. International Journal of Agronomy and Plant Production 4(5):950-962.

KiećJ, Wieczorek D (2009). Investigation on aqeous plant extracts tested as biologically active factors used for weed control. Progress in Plant Protection 49(1):371-377 [in Polish].

Koger CH, Reddyk N, Postond H (2004). Factors affecting seed germination, seedling emergence, and survival of texasweed (Caperonia palustris). Weed Science 52(6):989-995.

Kraska P, Kwiecinska-Poppe E (2007). The influence of water extract from Apera spica-venti on germination energy and germination capacity of Secale cereale and Triticosecale. Annales UMCS 62(2):127-136 [in Polish].

Lawrence BM (2007). Mint. The Genus Mentha. Medicinal and Aromatic Plants - Industrial Profiles. CRC Press London.

Lipinska H (2006). Kielkowanie nasion i wzrost siewek wybranych gatunkow traw w warunkach oddzialywania blastokolin kielkujacych nasion traw. Acta Agrobotanica 59(2):253-262 [in Polish].

Macias FA, Lopez A, Verela RM, Torres A, Molinillo JMG (2002). Bioactive terpenoids from sunflower leaves cv. Peredovic. Phytochemistry 61:687-692.

Marczewska-Kolasa K, Bortniak M, Sekutowski TR, Domaradzki K (2017). Influence of water extracts from cornflower on germination and growth of cereals seedlings. Journal of Research and Applications in Agricultural Engineering62(3):208-211.

Mozdzen K, Repka P (2014). Allelopathic influence of aqueous extracts from the leaves Morus alba L. on seed germination and seedling growth of Cucumis sativus L. and Sinapsis alba L. Modern Phytomorphology 5:93-99.

Mutlu S, Atici O, Esim N, Mete E (2011). Essential oils of catmint (Nepeta meyeri Benth.) induce oxidative stress in early seedlings of various weed species. Acta Physiology Plant 33:943-951.

Mystkowska I, Zarzecka K, Baranowska A, Gugala M (2016). Peppermint herb plant with multiple phytochemical properties. Herbalism 2:117127 [in Polish].

Newerli-GuzJ (2016). The cultivation of herbal plants in Poland. Annals of the Polish Association of Agricultural and Agribusiness Economists 18(3):268-274 [in Polish].

Nik MM, Babaeian M, Tavassol A (2011). Effect of seed size and genotype on germination characteristic and seed nutrient content of wheat. Scientific Research andEssays 6(9):2019-2025.

Pula J, Barabasz-Krasny B, Mozdzen K, Soltys-Lelek A, Lepiarczyk A (2016). Effect of aqueous extracts of Sticky willy (Galium aparine L.) on the growth of seedlings of selected maize varieties (Zea mays L.). Notulae Botanicae Horti Agrobotanici Cluj-Napoca 44(2):518-524.
Rice EL (1984). Allelopathy, $2^{\text {nd }}$ edition. Academic Press. Orlando, USA pp 67-68.

Ridenour WM, Callaway RM (2001). The relative importance of allelopathy in interference: the effects of an invasive weed on a native bunchgrass. Oecologia 126:444 450.

Rita P, Animesh DK (2011). An updated overview on peppermint (Mentha $\times$ piperita L.).International Research Journal of Pharmacy 2:1-10.

Sadeghi H, Khazaei F, Sheidaei S, Yari L (2011). Effect of seed size on seed germination behavior of safflower (Carthamus tinctorius L.). ARPN Journal of Agricultural and Biological Science 6(4):5-8.

Saharkhiz MJ, Esmaeili S, Merikhi M (2010). Essential oil analysis and phytotoxic activity of two ecotypes of Zataria multiflora Boiss. growing in Iran. Natural Product Research 24(17):1598-1609.

Sanders D, Bethke P (2000). Membrane transport. In: Buchanan B, Gruissem W, Jones R (Eds). Biochemistry and Molecular Biology of Plants. American Society of Plant Physiologists, Rockville pp 110-159.

Sekutowski T (2010). Alleloherbicides and bioherbicdes - myth or reality? Journal of Research and Applications in Agricultural Engineering 55(4):84-90 [in Polish].

Siyar S, Chaudhry Z, Hussain F, Hussain Z, Majeed A (2017). Allelopathic effects of some common weeds prevailing in wheat fields on growth characteristics of wheat (Triticum aestivum L.).PSMBiological Research 2(3):124-127.

Skrzypek E, Repka P, Stachurska-Swakon A, Barabasz-Krasny B, Mozdzen $\mathrm{K}$ (2015a). Allelopathic effect of aqueous extracts from the leaves of peppermint (Mentha xpiperita L.) on selected physiological processes of common sunflower (Helianthus annuus L.). Notulae Botanicae Horti Agrobotanici Cluj-Napoca 43(2):335-342.

Skrzypek E, Repka P, Stachurska-Swakon A, Barabasz-Krasny B, Mozdzen $\mathrm{K}$ (2015b). Influence of extracts from peppermint (Mentha xpiperita (L.) Hudson) on growth and activity of the PSII sunflower garden (Helianthus annuus L.). In: Bryndza J, Klymenko S (Eds). Agrobiodiversity for Improving Nutrition, Health and Life Quality 2:631-634.

Skrzypek E, Repka P, Stachurska-Swakon A, Barabasz-Krasny B, Mozdzen $\mathrm{K}$ (2016). Seedlings growth of common sunflower under influence of peppermint extract. Modern Phytomorphology 9:69-73.

Szweykowska A, Szweykowski J (2003). Botany dictionary. Universal Knowledge. Warszawa pp 516-517 [in Polish].

Takeuchi S, Tamaoki L, Kondo M, Konno K(1994). Effect of menthol on cytosolic $\mathrm{Ca}^{2+}$ levels in canine airway epithelium in culture. Biochemical and Biophysical Research Communications 201:1333-1338.

Teaca CA, Bodirla UR, Oprea A, Colceru S (2008). Influence of plant extracts on germination and post - germination development of different species. Cellulose Chemistry and Technology 42(1):121-127.

Tsuzuki E, Dong Y (2003). Buckwheat allelopathy: use in weed management. Allelopathy Journal 12:1-12. 